\title{
SEASONAL AND INTER-ANNUAL VARIATIONS OF PCB AND DDT CONTENTS IN THE OYSTER Crassostrea angulata FROM THE SADO ESTUARY (PORTUGAL)
}

\section{VARIACIONES ESTACIONALES E INTERANUALES DE LOS CONTENIDOS DE PCB Y DDT EN EL OSTIÓN Crassostrea angulata DEL ESTUARIO DE SADO (PORTUGAL)}

\author{
Ana Maria Ferreira* \\ Carlos Vale \\ Instituto de Investigação das Pescas e do Mar \\ Av. Brasilia \\ 1400 Lisboa, Portugal \\ * E-mail: amfer@ipimar.pt
}

Recibido en agosto de 2000; aceptado en febrero de 2001

\begin{abstract}
Concentrations of 16 PCB congeners, pp'-DDT and its metabolites (DDE and DDD) and lipid content were determined in Crassostrea angulata. The oysters were collected monthly from a natural ground of the upper Sado Estuary, from November 1987 to November 1988, and between January and December 1990. The same compounds were also analysed in suspended particulate matter samples collected at the same site with the same periodicity. In 1987/88, the suspended particulate matter contained uniformly low levels of pp'-DDT and its metabolites (1-5 $\left.\mathrm{ng} \mathrm{g}^{-1}\right)$, except in the winter runoff period when DDT compounds reached $48 \mathrm{ng} \mathrm{g}^{-1}$. The river flows remained low throughout 1990 and no seasonal variation of DDT contents was found in the suspended particulate matter. Concentrations of PCBs as the sum of congeners remained within the narrow interval of 5-12 $\mathrm{ng} \mathrm{g}^{-1}$ in the two years. The seasonal profiles of DDT and PCB compounds in oysters were characterized by the presence of a spring peak associated with the sexual cycle, and another maximum in winter. The winter peak in 1987/88 results from the input of particles enriched in DDT and the downward displacement of the maximum turbidity zone, whereas the 1990 peak was related to nutritional alterations. These results show that the accumulation pattern of organochlorines in oysters varied seasonally and inter-annually according to the timing of environmental and biological factors.
\end{abstract}

Key words: PCBs, DDT and metabolites, bioaccumulation, oyster, Crassostrea angulata.

\section{RESUMEN}

Se determinaron las concentraciones de 16 congéneres de PCB, de pp'-DDT y sus metabolitos (DDE y DDD) y el contenido de lípidos en Crassostrea angulata. Los ostiones fueron recolectados mensualmente de un banco natural en la parte superior del estuario de Sado, de noviembre de 1987 a noviembre de 1988 y de enero a diciembre de 1990. Estos compuestos también fueron analizados en muestras de materia particulada en suspensión, recolectadas en el mismo sitio y durante los mismos periodos. En 
Ciencias Marinas, Vol. 27, No. 2, 2001

1987/88, el material particulado en suspensión tuvo niveles uniformemente bajos de pp'-DDT y sus metabolitos (1-5 ng g ${ }^{-1}$ ), excepto en el periodo de descarga fluvial de invierno, cuando los compuestos de DDT alcanzaron $48 \mathrm{ng} \mathrm{g}^{-1}$. Los flujos del río permanecieron bajos durante todo 1990 y no se encontró ninguna variación estacional en los contenidos de DDT de la materia particulada en suspensión. Las concentraciones de los PCBs como la suma de los congéneres permaneció dentro de un estrecho intervalo de 5 a $12 \mathrm{ng} \mathrm{g}^{-1}$, durante los dos años. Los perfiles estacionales de los componentes de DDT y PCB en los ostiones se caracterizaron por la presencia de un pico máximo en la primavera, asociado con el ciclo sexual, y de otro máximo en invierno. El máximo de invierno en 1987/88 resulta de la entrada de partículas enriquecidas en DDT y del desplazamiento estuario abajo de la zona de turbidez máxima, mientras que el pico máximo de 1990 se relacionó con alteraciones en la nutrición. Estos resultados muestran que el modelo de acumulación de los compuestos organoclorados en los ostiones varió estacional e interanualmente de acuerdo con la cronología de los factores ambientales y biológicos.

Palabras clave: PCB, DDT y metabolitos, bioacumulación, ostión, Crassostrea angulata.

\section{INTRODUCTION}

Despite restrictions to the use of polychlorinated biphenyls (PCBs) and DDT in the last decades, their cycling in aquatic ecosystems is still a matter of concern due to their persistence and toxicity (Dachs et al., 1997; Willman et al., 1997). Most of these compounds have short residence times in water, being rapidly adsorbed onto suspended particulate matter (Duursma et al., 1986) and accumulated in sediments and organisms (Dannerberger, 1996). Bivalves have been studied extensively and used in biomonitoring programs due to their ability to concentrate organochlorine compounds in proportion to their contents in the aquatic environment (Farrington, 1983; Colombo et al., 1997). Beyond changes due to alterations of environmental availability, tissue residues are related to lipid fluctuations (Farrington, 1983; Phillips and Rainbow, 1994), which are generally associated with the gametogenesis/spawning period (Lowe et al., 1971; Marchand and Duursma, 1976; Gutiérrez-Galindo et al., 1984) and nutritional insufficiencies (DeslousPaoli et al., 1982).

This work reports the seasonal variations of PCB congeners and DDT and its metabolites in

\section{INTRODUCCIÓN}

A pesar de las restricciones en el uso de los bifenilos policlorados (PCBs, por sus siglas en inglés) y del DDT en las últimas décadas, su circulación en los ecosistemas acuáticos todavía es materia de preocupación debido a su persistencia y toxicidad (Dachs et al., 1997; Willman et al., 1997). La mayoría de estos compuestos tienen cortos tiempos de residencia en el agua, ya que rápidamente se adsorben al material particulado en suspensión (Duursma et $a l ., 1986)$ y se acumulan en sedimentos y organismos (Dannerberger, 1996). Los bivalvos han sido ampliamente estudiados, además de ser utilizados en programas de biomonitoreo, debido a su capacidad para concentrar los compuestos organoclorados en proporción al contenido de estos últimos en el ambiente acuático (Farrington, 1983; Colombo et al., 1997). Más allá de los cambios debidos a las variaciones en su disponibilidad en el medio, sus residuos en el tejido están relacionados con fluctuaciones de los lípidos (Farrington, 1983; Phillips y Rainbow, 1994), generalmente asociadas con el periodo de gametogénesis/desove (Lowe et al., 1971; Marchand y Duursma, 1976; GutiérrezGalindo et al., 1984) y con deficiencias en la nutrición (Deslous-Paoli et al., 1982). 
oysters from the upper Sado Estuary during two annual periods. The different river flow discharges occurred in two periods, allowing the effect of the environmental availability of microcontaminants to be separated from the physiological factors in the bioaccumulation processes.

\section{MATERIAL AND METHODS}

\section{Sampling}

Specimens of the oyster Crassostrea angulata of approximately $5 \mathrm{~cm}$ were collected from a natural ground of the upper Sado Estuary. The oysters were sampled monthly, between November 1987 and November 1988, and from January to December 1990. The individuals were measured, weighed and dissected, and soft-tissue composite samples of 25 oysters were freeze-dried and homogenized. Suspended particulate matter was collected with the same periodicity in the oyster ground site. During the 1987/88 period surveyed, surface and near-bottom water was taken, in correspondence with low and high spring tides, and the suspended particulate matter was obtained by filtration under $\mathrm{N}_{2}$ pressure through pretreated $1-\mu \mathrm{m}$ glass-fibre filters (Gelman A/E) of $143 \mathrm{~mm}$. During 1990, suspended particulate matter was collected into sediment traps placed $50 \mathrm{~cm}$ above the sediment surface. The traps consisted of 7-cm i.d. tubes inserted inside cement structures.

\section{Analysis}

PCB congeners and DDT and its metabolites in suspended particulate matter and oysters were soxhlet-extracted in $n$-hexane for 16 and 6 hours, respectively. The extracts were purified by a Florisil column $\left(1 \% \mathrm{H}_{2} \mathrm{O}\right)$ eluted with hexane and dichloromethane/hexane (30:70), following the procedure described in
Este trabajo reporta las variaciones estacionales de los congéneres de PCB y de DDT y sus metabolitos, en ostras de la porción superior del estuario de Sado durante dos periodos anuales. Las diferentes descargas del río ocurrieron en dos periodos, lo que permitió separar el efecto de la disponibilidad de los microcontaminantes en el medio de los factores fisiológicos que intervienen en los procesos de bioacumulación.

\section{MATERIAL Y MÉTODOS}

\section{Muestreo}

Se recolectaron especímenes del ostión Crassostrea angulata de aproximadamente $5 \mathrm{~cm}$ de un banco natural en la parte superior del estuario de Sado. Los ostiones se muestrearon mensualmente de noviembre de 1987 a noviembre de 1988 y de enero a diciembre de 1990. Los individuos se midieron, pesaron y disecaron, obteniendo muestras compuestas de tejido blando de 25 ostiones, que fueron liofilizadas y homogeneizadas. La materia particulada en suspensión fue recolectada en el mismo periodo, en el sitio ocupado por el banco de ostión. Durante el periodo de 1987/88 investigado, se tomaron muestras de agua de la superficie y del fondo, correspondiendo a las mareas vivas, alta y baja, y el material particulado en suspensión se obtuvo por filtración a presión de $\mathrm{N}_{2}$, a través de filtros pretratados de fibra de vidrio $1 \mu \mathrm{m}$ (Gelman A/E) de $143 \mathrm{~mm}$. Durante 1990, la materia particulada en suspensión se recolectó en trampas de sedimento colocadas $50 \mathrm{~cm}$ arriba de la superficie de los sedimentos. Las trampas consistían en tubos de $7 \mathrm{~cm}$ d.i., insertados en estructuras de cemento.

\section{Análisis \\ Los congéneres de PCB y el DDT y sus metabolitos en la materia particulada en}


Ciencias Marinas, Vol. 27, No. 2, 2001

Ferreira and Vale (1995). The organochlorine residues were determined using a HewlettPackard 5880A gas-chromatograph with electron capture detector and capillary column, DB5, J\&W, $60 \mathrm{~m}$. Sixteen PCB congeners with several degrees of chlorination, i.e., tri$(18,26)$, tetra- $(44,49,52)$, penta- $(101,118)$, hexa- $(128,138,149,151)$ and heptachlorobiphenyls $(170,180,183,187)$, together with pp'-DDE, pp'-DDD and pp'-DDT were analysed. The compounds were identified and quantified through the use of a mixture of PCB congeners (PCB-11, IOC-Kiel) and EPA standards. The analytical detection limits of PCB congeners and DDT compounds for oysters were $0.1 \mathrm{ng} \mathrm{g}^{-1}$ and for suspended particulate matter, $0.2 \mathrm{ng} \mathrm{g}^{-1}$. The mean recovery of these compounds in the two materials analysed was $93 \pm 16.2 \%$. The concentrations in both oysters and suspended particulate matter are expressed in dry weight. Microcontaminants in suspended particulate matter of $1987 / 88$ correspond to mean concentrations in the material collected from the surface and the bottom at low and high tide. Lipid concentrations in oyster samples were determined by weighting the hexane-extracted components.

\section{Riverine and estuarine conditions}

The Sado River presented contrasting hydrological conditions in the winters of the two study years (fig. 1). The river flow increased sharply in three short periods between November 1987 and February 1988, reaching a maximum of $250 \mathrm{~m} \mathrm{~s}^{-1}$, which exceeded largely the mean winter value $\left(28 \pm 41.2 \mathrm{~m}^{3} \mathrm{~s}^{-1}\right)$. On the contrary, the flow in winter 1990 was uniformly low (14 \pm $8.9 \mathrm{~m}^{3} \mathrm{~s}^{-1}$ ), with no sharp increases. In the other seasons of both years, the river flow was around $4 \mathrm{~m}^{3} \mathrm{~s}^{-1}$. suspensión y en los ostiones fueron extraídos mediante el método soxhlet en $n$-hexano durante 16 y 6 horas, respectivamente. Los extractos se purificaron por medio de una

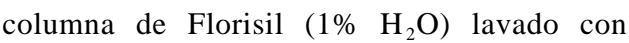
hexano y diclorometano/hexano (30:70), siguiendo el procedimiento descrito por Ferreira y Vale (1995). Los residuos organoclorados fueron determinados usando un cromatógrafo de gases Hewlett-Packard 5880A con detector de captura de electrones y columna capilar, DB5, J\&W, $60 \mathrm{~m}$. Se analizaron 16 congéneres de PCB, con diversos grados de cloración, i.e., bifenilos triclorados $(18,26)$, tetraclorados $(44,49,52)$, pentaclorados $(101,118)$, hexaclorados $(128,138$, $149,151)$ y heptaclorados $(170,180,183,187)$, junto con el pp'-DDE, pp'-DDD y pp'-DDT. Los compuestos se identificaron y cuantificaron usando una mezcla de congéneres de PCB (PCB-11, IOC-Kiel) y los estándares de la EPA. Los límites de detección analítica de los congéneres de PCB y los compuestos de DDT fueron de $0.1 \mathrm{ng} \mathrm{g}^{-1}$ para los ostiones y de $0.2 \mathrm{ng} \mathrm{g}^{-1}$ para la materia particulada en suspensión. La recuperación media de estos compuestos en los dos materiales analizados fue de $93 \pm 16.2 \%$. Las concentraciones, tanto en los ostiones como en la materia particulada en suspensión, son expresadas en peso seco. Los microcontaminantes en la materia particulada en suspensión en 1987/88 corresponden a las concentraciones medias en el material recolectado de la superficie y del fondo en marea baja y alta. Las concentraciones de lípidos en las muestras de ostión fueron determinadas pesando los componentes extraídos con hexano.

\section{Condiciones fluviales y estuarinas}

El Río Sado presentó condiciones hidrológicas contrastantes durante los inviernos de los 


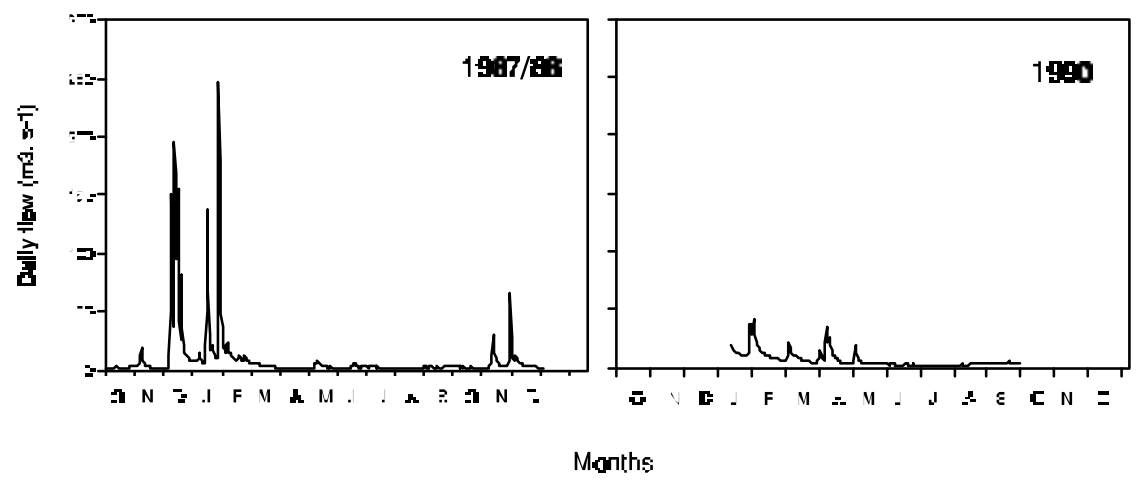

Figure 1. Daily measurements of Sado River flow $\left(\mathrm{m}^{3} \mathrm{~s}^{-1}\right)$ at Gamitinha between October 1987 and December 1988, and from January to December 1990 (source: Caudais Ano Hidrológico 1987/88 and 1989/90, Hydraulic Services).

Figura 1. Mediciones diarias del flujo $\left(\mathrm{m}^{3} \mathrm{~s}^{-1}\right)$ del Río Sado en Gamitinha entre octubre de 1987 y diciembre de 1988 y de enero a diciembre de 1990 (fuente: Caudais Ano Hidrológico 1987/88 y 1989/90, Servicios Hidráulicos).

The estuary exhibits a maximum turbidity zone centred at the upper limit of salinity; the suspended sediment concentrations reaches $500 \mathrm{mg} \mathrm{L}^{-1}$ during spring tide. The turbidity decreases significantly downstream to $50 \mathrm{~m} \mathrm{~g} \mathrm{~L}^{-1}$ in the oyster zone. In winter 1988 , due to hard runoff, the turbidity maximum exceeded $1000 \mathrm{mg} \mathrm{L}^{-1}$, and the centre of the turbidity zone was displayed downward to the oyster ground area. This situation continued until March 1988. Suspended sediment concentration did not increase considerably in winter 1990 and values in the oyster zone varied only with the tide. A more detailed information concerning the dynamics of the maximum turbidity zone in the Sado Estuary can be found in Vale et al. (1993).

\section{RESULTS}

\section{DDT compounds and PCB congeners in suspended particulate matter}

The concentrations of pp'-DDT, pp'-DDD and pp'-DDE in suspended particulate matter dos años estudiados (fig. 1). El flujo del río creció abruptamente durante tres cortos periodos entre noviembre de 1987 y febrero de 1988, alcanzando un máximo de $250 \mathrm{~m}^{3} \mathrm{~s}^{-1}$, que excedió en gran medida el valor invernal promedio $\left(28 \pm 41.2 \mathrm{~m}^{3} \mathrm{~s}^{-1}\right)$. Por el contrario, el flujo del río en el invierno de 1990 fue uniformemente bajo $\left(14 \pm 8.9 \mathrm{~m}^{3} \mathrm{~s}^{-1}\right)$, sin crecientes abruptas. En las demás estaciones de ambos años el flujo del río fue alrededor de $4 \mathrm{~m}^{3} \mathrm{~s}^{-1}$.

El estuario muestra una zona de turbidez máxima centrada en el límite superior de salinidad; las concentraciones de sedimento suspendido alcanzan $500 \mathrm{mg} \mathrm{L}^{-1}$ en las mareas vivas. La turbidez disminuye significativamente río abajo, hasta $50 \mathrm{mg} \mathrm{L}^{-1}$ en la zona de los ostiones. En el invierno de 1988, debido a las fuertes descargas, la turbidez máxima excedió los $1000 \mathrm{mg} \mathrm{L}^{-1}$ y el centro de la zona de turbidez se desplazó estuario abajo, al área del banco de ostiones. Esta situación se mantuvo hasta marzo de 1988. La concentración de sedimentos en suspensión no se incrementó considerablemente en el invierno de 1990 y los valores en la zona ostrícola 

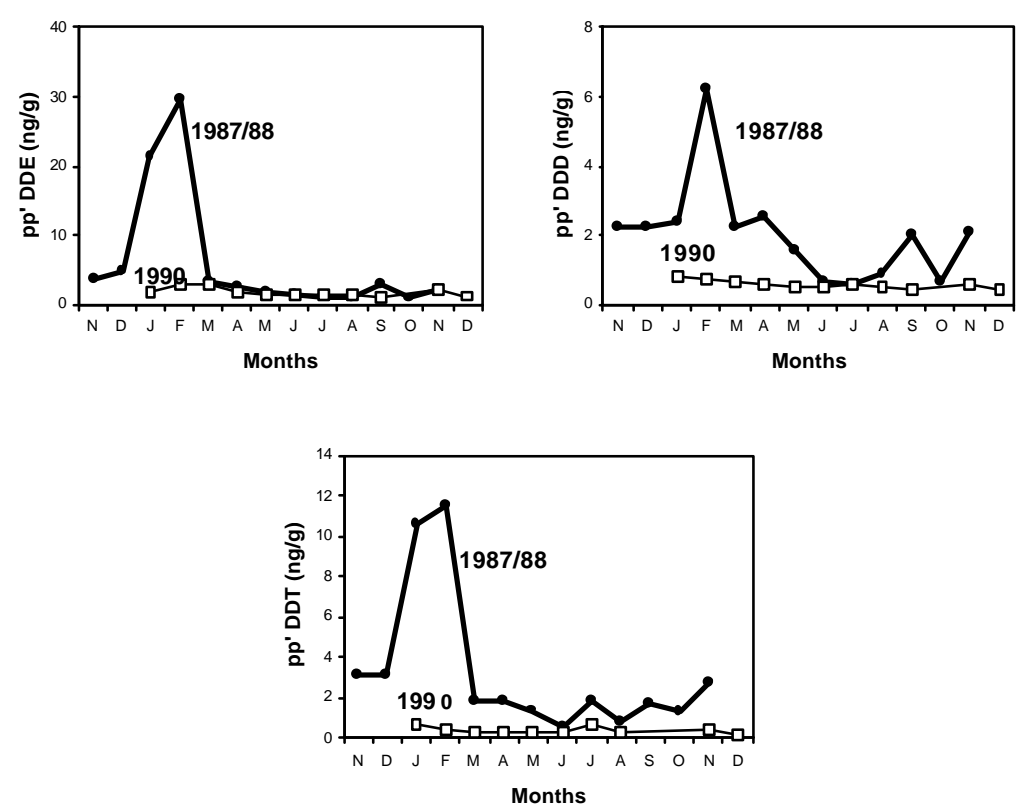

Figure 2. Seasonal variation of pp'-DDE, pp'-DDD and pp'-DDT concentrations (ng $\mathrm{g}^{1}$, d.w.) in suspended particulate matter collected in the upper Sado Estuary in 1987/88 (circles) and 1990 (squares). Figura 2. Variación estacional de las concentraciones de pp'-DDE, pp'-DDD y pp'-DDT (ng g ${ }^{-1}$, p.s.) en el material particulado en suspensión recolectado del estuario de Sado superior en 1987/88 (círculos) y 1990 (cuadrados).

and their seasonal variations differed considerably in the two years (fig. 2). Whilst the levels of p,p'-DDT and its metabolites in 1990 were from 1 to $5 \mathrm{ng} \mathrm{g}^{-1}$, in winter 1988, p,p'-DDE increased to $30 \mathrm{ng} \mathrm{g}^{-1}, \mathrm{p}, \mathrm{p}^{\prime}$-DDT to $12 \mathrm{ng} \mathrm{g}^{-1}$ and pp'-DDD to $6 \mathrm{ng} \mathrm{g}^{-1}$. However, the proportions of DDT compounds in suspended particulate matter of the two annual periods were not significantly different $\varphi<0.05)$. The major component was p,p'-DDE, with a mean value of $56 \pm 14.0 \%$, followed by p,p'-DDD and p,p'-DDT, with $23 \pm 6.7 \%$ and $19 \pm 9.2 \%$, respectively.

The seasonal concentrations of tri-, tetra-, penta-, hexa- and hepta-chlorinated biphenyls in 1987/88 and 1990 are shown in figure 3. Values of tri- and tetra-chlorinated compounds were comparable in the two years, and fluctuaron solamente con la marea. En la publicación de Vale et al. (1993) se puede encontrar información más detallada con relación a la dinámica de la zona de máxima turbidez en el estuario de Sado.

\section{RESULTADOS}

\section{Compuestos de DDT y congéneres de PCB en la materia particulada en suspensión}

Las concentraciones de pp'-DDT, pp'DDD y pp'-DDE en la materia particulada en suspensión y sus fluctuaciones estacionales difirieron considerablemente en los dos años (fig. 2). Mientras que en 1990 los niveles de p,p'-DDT y sus metabolitos fueron de 1 a $5 \mathrm{ng} \mathrm{g}^{-1}$, en el invierno de 1988 el p,p'-DDE se 
slight increases of penta-, hexa- and heptachlorinated compounds were found in February 1988. The proportions of the PCB congeners analysed were not significantly different in both years, the major components being CB18 (tri-), CB138 (hexa-), CB149 (hexa-) and CB180 (hepta-chlorinated), each one accounting for more than $10 \%$ of the total.

\section{DDT compounds, PCB congeners and lipid contents in oysters}

The levels of DDT compounds in oysters revealed a seasonal variation with sharp peak concentrations in winter and spring (fig. 4). The pattern was similar in the two years, although the winter peak in 1987/88 doubled the intensities found in 1990. The proportions of DDT compounds in both years were not significantly different $p<0.05)$, the major component being p,p'-DDE (67 $\pm 14.0 \%)$, followed by p,p'-DDD $(24 \pm 10.3 \%)$ and p,p'-DDT $(9 \pm 6.3 \%)$.

The seasonal variations of PCB congeners in oysters (fig. 5) were comparable to those found for DDT compounds: sharp peak concentrations in winter and in spring of the two years, and higher increases in winter 1987/88. In both years, the major components of the PCB congeners were the hexachlorinated compounds $\mathrm{CB} 138$ and $\mathrm{CB} 149$, each one accounting for more than $15 \%$ of the total PCB congeners analysed. The proportions of the congeners were not significantly different $(p<0.05)$ in the two annual periods.

Seasonal variations of lipid contents in the oyster C. angulata are presented in figure 6 . From November 1987 to April 1988, lipids remained between $2.8 \%$ and $4.5 \%$, then presented a maximum in June $(7.1 \%)$ and increased until November. In 1990, two sharp peaks were observed in January $(7.1 \%)$ and May $(9.2 \%)$. incrementó a $30 \mathrm{ng} \mathrm{g}^{-1}$, el p,p'-DDT a $12 \mathrm{ng} \mathrm{g}^{-1}$ y el pp'-DDD a $6 \mathrm{ng} \mathrm{g}^{-1}$. Sin embargo, las proporciones de los compuestos de DDT en el material particulado en suspensión de los dos periodos anuales no difirió significativamente $(p<0.05)$. El componente principal fue el p,p'-DDE, con un valor medio de $56 \pm 14.0 \%$, seguido por el p,p'-DDD y el p,p'-DDT, con $23 \pm 6.7 \%$ y $19 \pm 9.2 \%$, respectivamente.

En la figura 3 se muestran las concentraciones estacionales de los bifenilos tri, tetra, penta, hexa y heptaclorados en 1987/88 y 1990. Los valores de los compuestos tri y tetraclorados fueron comparables en los dos años y se encontraron ligeros incrementos de los compuestos penta, hexa y heptaclorados en febrero de 1988. En los dos años no se encontraron diferencias significativas en las proporciones analizadas de los congéneres de $\mathrm{PCB}$, siendo los principales componentes el CB18 (triclorado), CB138 (hexaclorado), CB149 (hexaclorado) y CB180 (heptaclorado), cada uno con una contribución mayor que $10 \%$ al total.

\section{Contenidos de compuestos de DDT, de congéneres de PCB y de lípidos en los ostiones}

Los niveles de los compuestos de DDT en los ostiones revelaron una fluctuación estacional con notables concentraciones máximas en invierno y primavera (fig. 4). El patrón fue similar en los dos años, aunque el máximo invernal de 1987/88 duplicó la intensidad del encontrado en 1990. Las proporciones de compuestos de DDT no presentaron diferencias significativas en los dos años $(p<0.05)$, siendo el principal componente el p,p'-DDE (67 \pm $14.0 \%)$, seguido por el p,p'-DDD (24 $\pm 10.3 \%)$ y p,p'-DDT $(9 \pm 6.3 \%)$.

Las variaciones estacionales de los congéneres de PCB en los ostiones (fig. 5) fueron comparables a las encontradas para los compuestos de DDT: elevadas concentraciones 

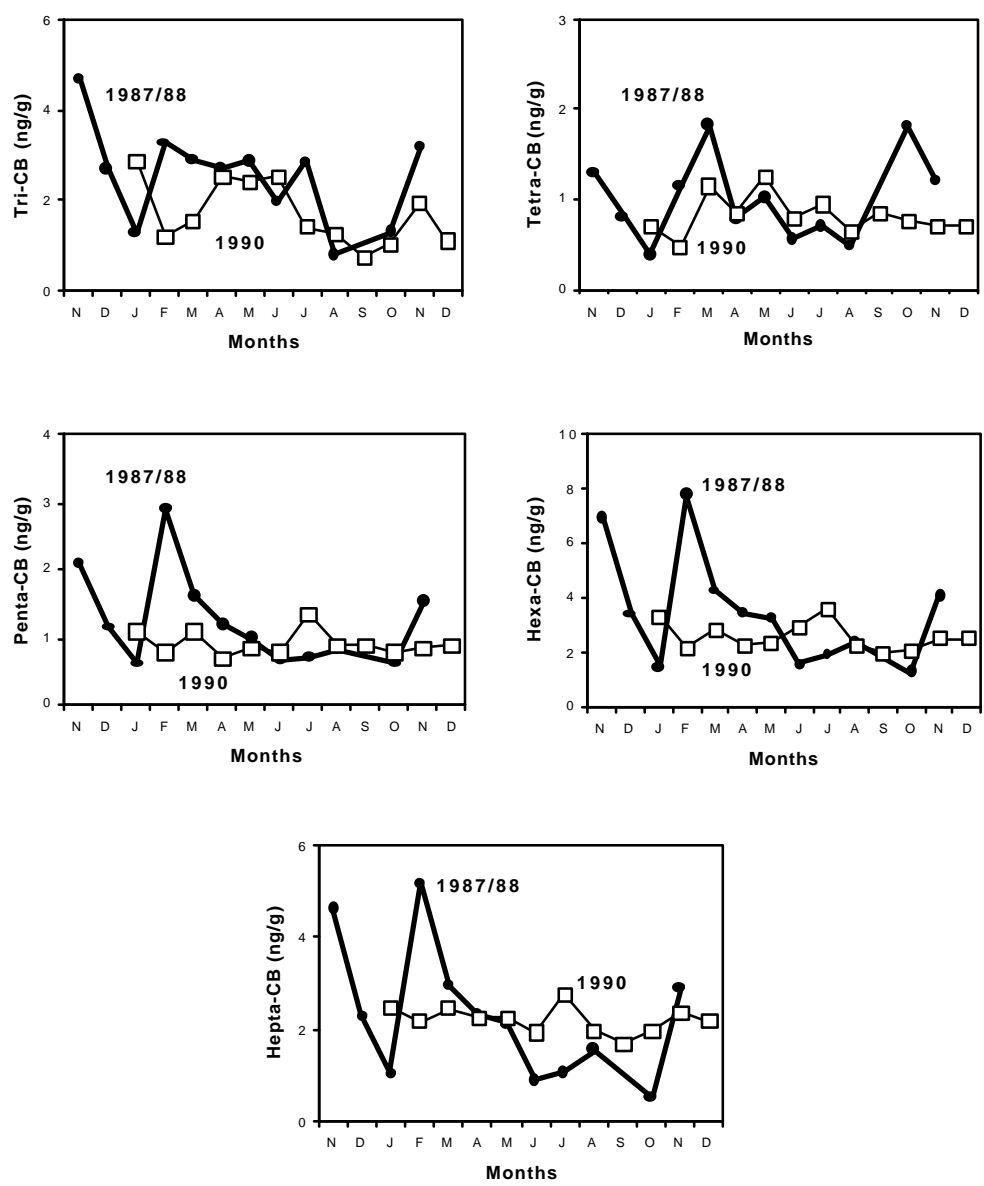

Figure 3. Seasonal variation of the concentrations of tri-, tetra-, penta-, hexa- and hepta-chlorinated PCB congeners ( ng g $^{-1}$, d.w.) in suspended particulate matter collected in the upper Sado Estuary in 1987/88 (circles) and 1990 (squares).

Figura 3. Variación estacional en las concentraciones de los congéneres tri, tetra, penta, hexa y heptaclorados del PCB (ng g ${ }^{-1}$, p.s.) en el material particulado en suspensión recolectado del estuario de Sado superior en 1987/88 (círculos) y 1990 (cuadrados).

\section{DISCUSSION}

The seasonal variations of PCB and DDT contents in $C$. angulata, collected from natural grounds of the upper Sado Estuary in two contrasting hydrologic regimes, reflect alterations of metabolic processes and changes máximas en los inviernos y primaveras de ambos años e incrementos mayores en el invierno de 1987/88. En ambos años, los principales componentes de los congéneres de PCB fueron los compuestos hexaclorados CB138 y CB149, contribuyendo cada uno con más del 15\% del total analizado de congéneres 

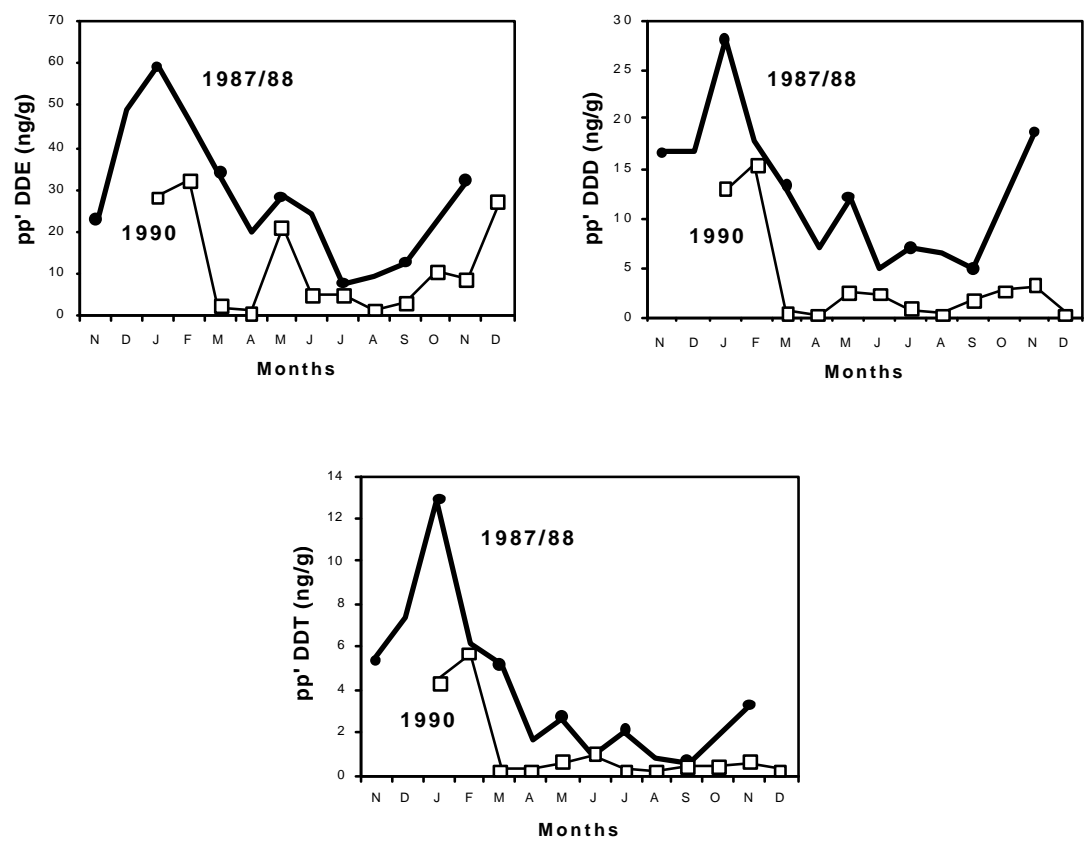

Figure 4. Seasonal variation of pp'-DDE, pp'-DDD and pp'-DDT concentrations (ng g ${ }^{-1}$, d.w.) in oysters from the upper Sado Estuary, in 1987/88 (circles) and 1990 (squares).

Figura 4. Variación estacional de las concentraciones de pp'-DDE, pp'-DDD y pp'-DDT (ng g ${ }^{-1}$, p.s.) en ostiones del estuario de Sado superior, en 1987/88 (círculos) y 1990 (cuadrados).

of contaminant availability in the estuarine zone. The environmental effect emerged in the winter, characterized by runoff, which caused a displacement of the maximum turbidity zone to the oyster ground and an inputof particles enriched in DDT compounds. The predominance of pp'-DDE in these particles over the other metabolites indicates a lack of recent inputs of DDT. The metabolic factor occurred in spring of both 1988 and 1990, and in winter 1990, when the lipid content in oyster tissues increased significantly.

The application of DDT in Portugal ceased in the 1970s, but traces have been recorded inmussels from the coastal area in the 1980s, in particular near the estuary mouth (Vale et de PCB. Las proporciones de los congéneres no presentaron diferencias significativas $(p<0.05)$ en los dos periodos anuales.

En la figura 6 se presentan las variaciones estacionales del contenido de lípidos en el ostión C. angulata. Los lípidos se mantuvieron entre $2.8 \%$ y $4.5 \%$ de noviembre de 1987 a abril de 1988, después presentaron un máximo en junio (7.1\%) y se incrementaron hasta noviembre. En 1990, se observaron dos máximos pronunciados, en enero $(7.1 \%) \mathrm{y}$ mayo $(9.2 \%)$.

\section{DISCUSIÓN}

Las variaciones estacionales en los contenidos de PCB y DDT en C. angulata recolectado 

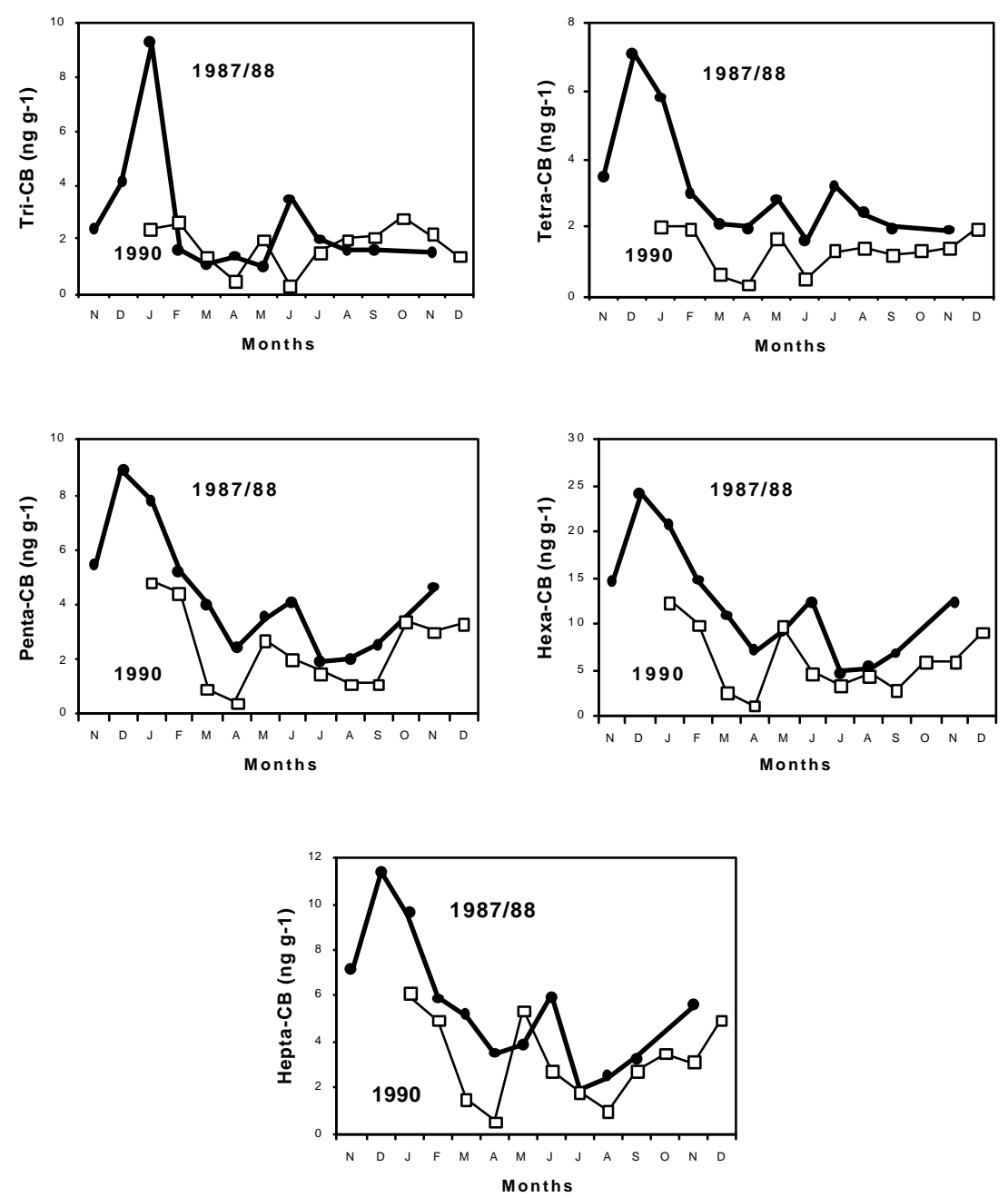

Figure 5. Seasonal variation of the concentrations of tri-, tetra-, penta-, hexa- and hepta-chlorinated PCB congeners (ng g ${ }^{-1}$, d.w.) in oysters from the upper Sado Estuary, in 1987/88 (circles) and 1990 (squares). Figura 5. Variación estacional de las concentraciones de los congéneres tri, tetra, penta, hexa y heptaclorados de PCB (ng g ${ }^{-1}$, p.s.) en ostiones del estuario de Sado superior, en 1987/88 (círculos) y 1990 (cuadrados).

al., 1985). Furthermore, analyses of fish, crustaceans and plankton sampled along the coast in recent years confirm the existence of DDT and its metabolites in the food web (Ferreira et al., unpublished data). The increase de los bancos naturales en la parte superior del estuario de Sado, durante dos regímenes hidrológicos contrastantes, reflejan alteraciones de los procesos metabólicos y cambios en la presencia del contaminante en la zona del 
Ferreira and Vale: Seasonal and inter-annual variations of PCB and DDT contents in C. angulata

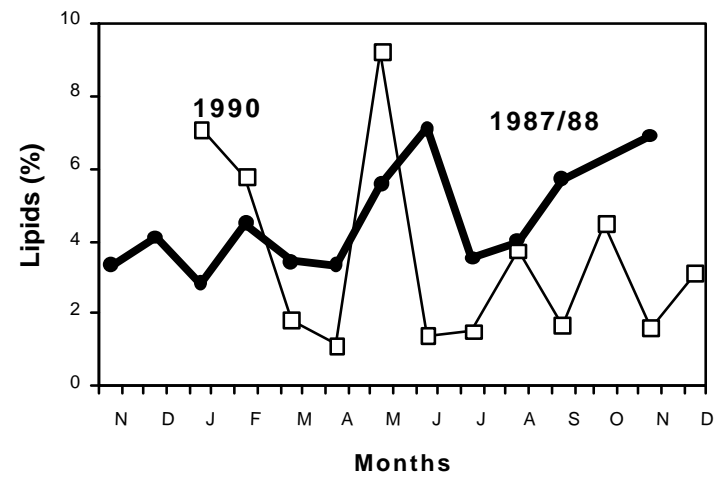

Figure 6. Lipid levels (\%, d.w.) in the oyster Crassostrea angulata from the the upper Sado Estuary, in $1987 / 88$ (circles) and 1990 (squares).

Figura 6. Niveles de lípidos (\%,p.s.) en el ostión Crassostrea angulata del estuario de Sado superior, en 1987/88 (círculos) y 1990 (cuadrados).

of p,p'-DDT and its metabolites in estuarine suspended particulate matter after periods of high river flows indicates that runoff causes a strong erosion of soil contaminated particles. Infact, it has been estimated that the annual transport of DDT compounds to the upper SadoEstuary was concentrated in these short periods (Ferreira and Vale, 1995). The increase of river flow caused a downward displacement of the maximum turbidity zone (Vale et al., 1993), and oysters experienced more turbid waters. The pronounced increases of pp'-DDE, pp'-DDD and pp'-DDT residues in oyster tissues are, therefore, attributed to the assumption of DDT-enriched particles due to the increase in turbidity. Because the increase of PCB residues in oysters was not related to the increase of their concentration in suspended particulate matter, higher accumulation of PCB appears to result from the larger amount of suspended particles in the water column.

Oysters presented high contents of DDT compounds and PCB congeners in the spring of both years. Since their concentrations in suspended particulate matter remained relatively constant during this period, it may be estuario. El efecto ambiental surgió en el invierno, caracterizado por la descarga del río, misma que causó el desplazamiento de la zona de turbidez máxima a los bancos de ostiones y la entrada de partículas ricas en compuestos deDDT. El predominio en estas partículas de pp'-DDE por encima de los otros metabolitos indica la ausencia de entradas recientes de DDT. El factor metabólico se presentó en la primavera de 1988 y de 1990, como en el invierno de 1990, cuando el contenido de lípidos en los tejidos del ostión aumentó significativamente.

La aplicación de DDT en Portugal se suspendió en los años setenta, pero se han registrado rastros de él en mejillones del área costera en los años ochenta, particularmente cerca de la boca del estuario (Vale et al.,1985). Además, algunos análisis de peces, crustáceos y plancton muestreados a lo largo de la costa en años recientes confirman la existencia de DDT y sus metabolitos en la cadena alimenticia (Ferreira et al., datos inéditos). El aumento del p,p'-DDT y sus metabolitos en la materia particulada en suspensión del estuario, después de periodos de intensas descargas fluviales, indica que estos 
Ciencias Marinas, Vol. 27, No. 2, 2001

inferred that the environmental availability of organochlorines did not change substantially. Therefore, higher residues in oysters can be attributed to changes in the lipid contents. In fact, lipid levels fluctuated in this period as a consequence of gonadal development and release of gametes (Vilela, 1975; Hummel et al., 1989), and concentrations of DDT compounds and PCB congeners parallel that fluctuation. These observations are in agreement with changes of organochlorine concentrations in bivalves during gametogenesis/spawning periods reported by many authors (Lowe et al., 1971; Marchand and Duursma, 1976; Gutiérrez-Galindo et al., 1984). A second peak of lipids was observed in winter 1990, accompanied by an increase of organochlorine concentrations. Since levels of organochlorine compounds in the environment were relatively constant due to the low river flow, higher residues in oysters appear to be driven again by metabolic processes. Indeed, lipid content decreased substantially in winter, probably as a consequence of nutritional insufficiencies. This hypothesis is corroborated by the decrease of organic carbon and extractable lipids in suspended particles (Ferreira and Vale, 1996). The ingestion of suspended particles with higher inorganic fraction led to the closing ofoyster valves and a consequent consumption of the reserve lipids (Deslous-Paoli et al., 1982).

The seasonal variations of DDT and PCB in $C$. angulata, from an upper estuarine zone exposed to occasional runoff episodes, allowed the determination of the effect of the environmental factor from the metabolic processes in the bioaccumulation process. TheDDT and PCB profiles exhibited seasonal as well as inter-annual variations according to the relative importance of these factors and their combination in different periods of the year. flujos causan una importante erosión de partículas del suelo contaminadas. De hecho, se ha estimado que el transporte anual de compuestos de DDT a la parte superior del estuario de Sado se concentraba en estos cortos periodos (Ferreira y Vale, 1995). El incremento en el flujo del río causó un desplazamiento de la zona de máxima turbidez hacia la parte inferior (Vale et al., 1993) y los ostiones estuvieron bajo la influencia de aguas más turbias. Por lo tanto, los incrementos pronunciados de residuos de pp'-DDE, pp'-DDD y pp'-DDT en los tejidos de los ostiones se atribuyen a la mayor presencia de partículas ricas en DDT, debido al aumento en la turbidez. Como el aumento de los residuos de PCB en los ostiones no estuvo relacionado con el aumento en su concentración en la materia particulada en suspensión, la mayor acumulación de PCB parece ser el resultado de la mayor cantidad de partículas suspendidas en la columna de agua.

Los ostiones presentaron altos contenidos de compuestos de DDT y congéneres de PCB en la primavera de ambos años. Dado que sus concentraciones en la materia particulada en suspensión permaneció relativamente constante durante este periodo, se puede inferir que la disponibilidad de organoclorados en el ambiente no varió substancialmente. Por consiguiente, las mayores concentraciones de residuos en los ostiones pueden atribuirse a los cambios en los contenidos de lípidos. De hecho, los niveles de los lípidos en este periodo fluctuaron como consecuencia del desarrollo gonadal y la liberación de gametos (Vilela, 1975; Hummel et al., 1989), y las concentraciones de los compuestos de DDT y de los congéneres de PCB presentan una fluctuación similar. Estas observaciones son acordes con los cambios en las concentraciones de organoclorados en bivalvos durante los periodos de gametogénesis/desove reportados por muchos 
Ferreira and Vale: Seasonal and inter-annual variations of PCB and DDT contents in C. angulata

\section{REFERENCES}

Colombo, J.C., Brochu, C., Bilos, C., Landoni, P. and Moore, S. (1997). Long-term accumulation of individual PCBs, dioxins, furans, and trace metals in Asiatic clams from the Río de la Plata estuary, Argentina. Environ. Sci. Technol., 31: 3551-3557.

Dachs, J., Bayona, J.M. and Albaigés, J. (1997). Spatial distribution, vertical profiles and budget of organochlorine compounds in western Mediterranean seawater. Mar. Chem., 57: 313-324.

Dannerberger, D. (1996). Chlorinated microcontaminants in surface sediments of the Baltic Sea: Investigations in the Belt Sea, the Arkona Sea and the Pomeranian Bight. Mar. Pollut. Bull., 32: 772-781.

Deslous-Paoli, J.M., Héral, M. and Zannette, Y. (1982). Problèmes posés par l'analyse des relations trophiques huitres-milieu. Cnexo (Actes Colloq.), 14: 335-340.

Duursma, E.K., Nieuwenhuize, J.M., Vanliere, J.M. and Hillebrand, M.T.J. (1986). Partitioning of organochlorines between water, particulate matter and some organisms in estuarine and marine systems of the Netherlands. Neth. J. Sea Res., 20: 239-251.

Farrington, J.W. (1983). Bivalves as sentinels of coastal chemical pollution: The mussel (and oyster) watch. Oceanus, 26: 18-29.

Ferreira, A.M. and Vale, C. (1995). The importance of runoff to DDT and PCB inputs to the Sado Estuary and Ria Formosa. Neth. J. Aquat. Ecol., 29: 211-216.

Ferreira, A.M. and Vale, C. (1996). The differences of PCB and lipid levels between settling/ resuspended materials and surface sediments of the Sado Estuary. Arch. Hydrobiol. Spec. Issues Adv. Limnol., 47: 547-552.

Gutiérrez-Galindo, E.A., Flores-Muñoz, G. and López-Mendoza, J.A. (1984). DDT in the cultured oyster Crassostrea gigas (Thunberg) in San Quintín Bay, Baja California. Ciencias Marinas, 10(3): 17-30.

Hummel, H., UitOudeGroeneveld, J.P., Nieuwenhuize, J., Van Liere, J.M., Bogaards, R.H. and De Wolf, L. (1989). Relationship between PCB concentrations and reproduction autores (Lowe et al., 1971; Marchand y Duursma, 1976; Gutiérrez-Galindo et al., 1984). En invierno de 1990, se observó una segunda concentración máxima de lípidos acompañada de un aumento en las concentraciones de organoclorados. Dado que, gracias al bajo flujo del río, los niveles de los compuestos organoclorados en el ambiente eran relativamente constantes, las mayores concentraciones residuales en los ostiones parecen estar de nuevo manejadas por procesos metabólicos. De hecho, el contenido de lípidos disminuyó substancialmente en invierno, probablemente a consecuencia de deficiencias en la nutrición. Esta hipótesis es corroborada por la disminución del carbono orgánico y los lípidos extraíbles en partículas suspendidas (Ferreira y Vale, 1996). La ingestión de partículas suspendidas con una mayor fracción inorgánica hace que el ostión cierre sus valvas consumiendo, en consecuencia, sus lípidos de reserva (DeslousPaoli et al., 1982).

Las variaciones estacionales de DDT y PCB en $C$. angulata, de una zona estuarina superior expuesta a episodios ocasionales de descarga fluvial, permitieron distinguir el efecto del factor ambiental del efecto de los procesos metabólicos, en el proceso de bioacumulación. Los perfiles del DDT y del PCB mostraron variaciones estacionales, así como interanuales, de acuerdo con la importancia relativa de estos factores y su combinación en diferentes periodos del año.

Traducido al español por Manuel Gardea. 
in mussels Mytilus edulis. Mar. Environ. Res., 28: 489-493.

Lowe, J.I., Wilson, P.D., Rick, A.J. and Wilson, A.J. (1971). Chronic exposure of oysters to DDT, toxaphene and parathion. Proc. Natl. Shellfisheries Assoc., 61: 71-79.

Marchand, M. and Duursma, E.K. (1976). Levels of PCBs and DDTs in mussels from the NW Mediterranean. Mar. Pollut. Bull., 7: 65-69.

Phillips, D.J.H. and Rainbow, P.S. (1994). Biomonitoring of Trace Contaminants. J. Cairns (ed.). Chapman and Hall, London, 371 pp.

Vale, C., Ferreira, A.M., Cortesão, C., Barros, M.C., Castro, O.G. and Mendes, R. (1985). A mussel watch in the Portuguese coast, 1984. ICES, C.M.1985/E, 18 pp.
Vale, C., Cortesão, C., Castro, O.G. and Ferreira, A.M. (1993). Suspended sediment response to pulses in the river flow and semi-diurnal and fortnightly tidal variations in a mesotidal estuary. Mar. Chem., 43: 21-31.

Vilela, H. (1975). A respeito de ostras. Biologiaexploração-salubridade. Crassostrea angulata (Lamark) em especial. Notas e Estudos da SEP, 1, Série Recursos e Ambiente Aquático, 220pp.

Willman, E.J., Manchester-Neesvig, J.B. and Armstrong, D.E. (1997). Influence of orthosubstitution on patterns of PCB accumulation in sediment, plankton, and fish in a freshwater estuary. Environ. Sci. Technol., 31: 3712-3718. 